\title{
Sedimentation And Provenance Patterns At an Active Plate Margin: the Cretaceous Xigaze Forearc Basin (Tibet)
}

\author{
Sören B. Dürr ', Werner Ricken ${ }^{2}$, and Gerhard Einsele ${ }^{3}$ \\ ${ }^{1}$ Mineralogical Institute, Am Hubland, D-97074 Würzburg, Germany \\ ${ }^{2}$ Geological Institute, Zülpicher Str. 49, D-50674 Köln, Germany \\ ${ }^{3}$ Geological Institute, Sigwartstrasse 10, D-72076 Tübingen, Germany
}

ABSTRACT

The E-W trending Xigaze forearc basin (South Tibet) formed by northward consumption of the Neotethys oceanic lithosphere under Eurasia. About $12 \mathrm{~km}$ of clastic sediment (the Xigaze Group) were deposited in the forearc basin, mainly by turbidity currents in five submarine fans. The lower $7 \mathrm{~km}$ are preserved in the study area and display three fining-upward supercycles. The Xigaze Group consists dominantly of volcaniclastic sediment with minor hemipelagic, carbonate-rich intercalations. A magmatic arc (Gangdese Belt), positioned on continental crust of the Lhasa Block to the north of the basin, served as major sediment source. The majority of its detritus is andesitic, but tonalitic material appears in younger deposits of the western Xigaze Group, pointing to increasing arc uplift in the west. Erosion of a carbonate shelf is indicated by carbonate clasts in the Xigaze Group. Arc uplift (northern basin flank), as a result of crustal thickening, was low during the Middle Cretaceous, but accelerated in the Late Cretaceous. The subduction complex was unable to serve as outer basin dam (southern basin flank), suggesting its small size. Synsedimentary tectonism is recorded in distal parts of the Xigaze Group and may be related to subduction complex growth, which resulted in evolution from a residual to a composite forearc basin.

\section{INTRODUCTION}

The Cretaceous Xigaze Group of southern Tibet represents the infill of a forearc basin, cropping out just south of the Transhimalayas (Fig. 1). Superb outcrop conditions in the Xigaze area provide an excellent opportunity to study, on a broad scale, this forearc sequence in front (south) of a continental magmatic arc (the Gangdese Belt). In this contribution, we present a summary of sedimentological and petrographical results, and attempt to highlight the forearc basin evolution, with a special reference to basin morphology.

The study was carried out as part of a joint project of the Geological Insitute of the University of Tübingen, Germany, and the Chengdu Institute of Geology and Mineral Resources of the P.R. China. Other topics of this project concentrated on the passive margin evolution of the Neotethys (Liu, 1992; Liu and Einsele, 1994), and on the collisional and post-collisional structural development of southern Tibet (Ratschbacher et al., 1992, in press).

The Xigaze forearc basin formed at the southern, active continental (Andean-type) margin of Eurasia (e.g., Allégre et al., 1984; Girardeau et al., 1984), when oceanic lithosphere of the Neotethys was being subducted northward during the Middle and Late Cretaceous (Fig. 2). The subduction zone trended EW over a distance of about $3000 \mathrm{~km}$. Continental collision occurred during the Paleogene, forming the Indus-Yarlung suture zone (IYSZ). Ophiolites of the IYSZ can be traced from eastern Tibet along the entire Himalayan chain to Ladakh in the west (Fig. 1). The forearc sequence, represented in Ladakh by the Indus Group (e.g., Garzanti and Van Haver, 1988), forms a more or less continuous band north of the suture, with its eastern termination about $40 \mathrm{~km}$ east of Xigaze (Fig. 1).

Detailed accounts on the sedimentology of the Xigaze Group are presented in Dürr (1993), Einsele et al. (1994), and Dürr and Ricken (in preparation). 
S. B. Durr et al.

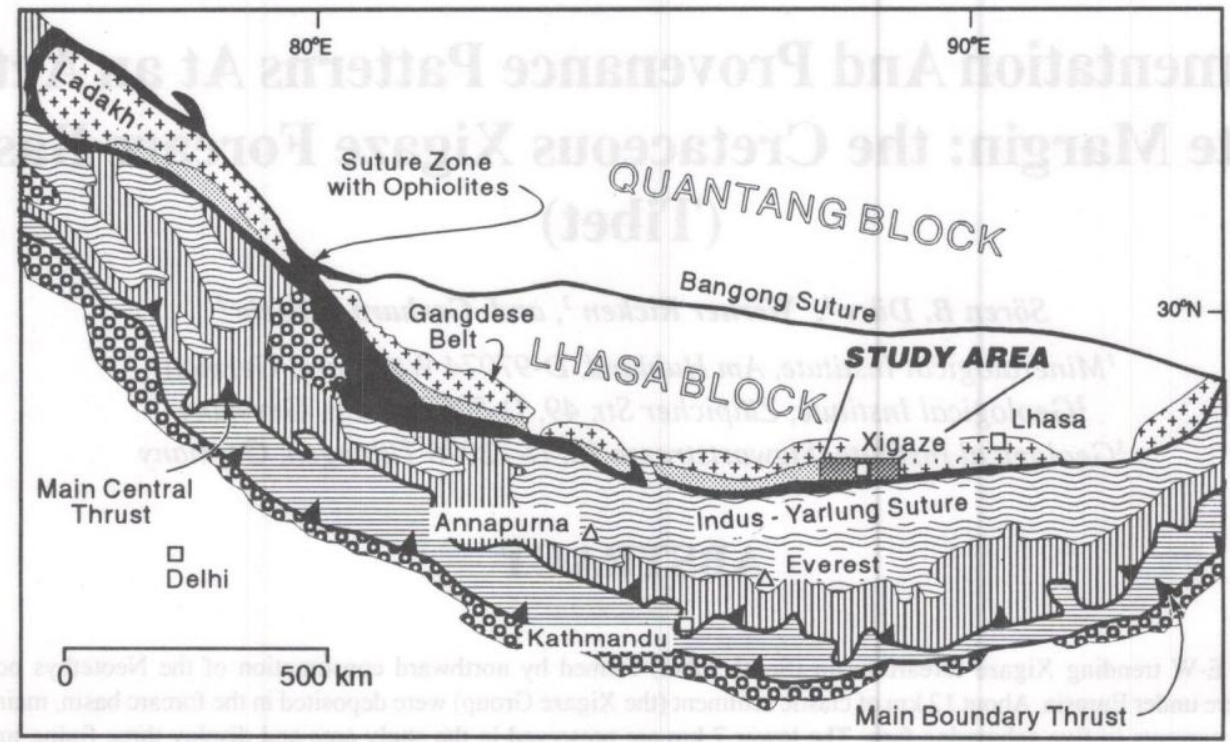

$\begin{array}{lll}\text { Ophiolites } & \text { 血 High Himalayas } & \text { Subhimalayas } \\ \text { (Siwaliks) }\end{array}$

Fig. 1 Geological sketch map of the Himalayan mountain chain (modified after Gansser, 1991), showing the location of the study area (dark rectangle)

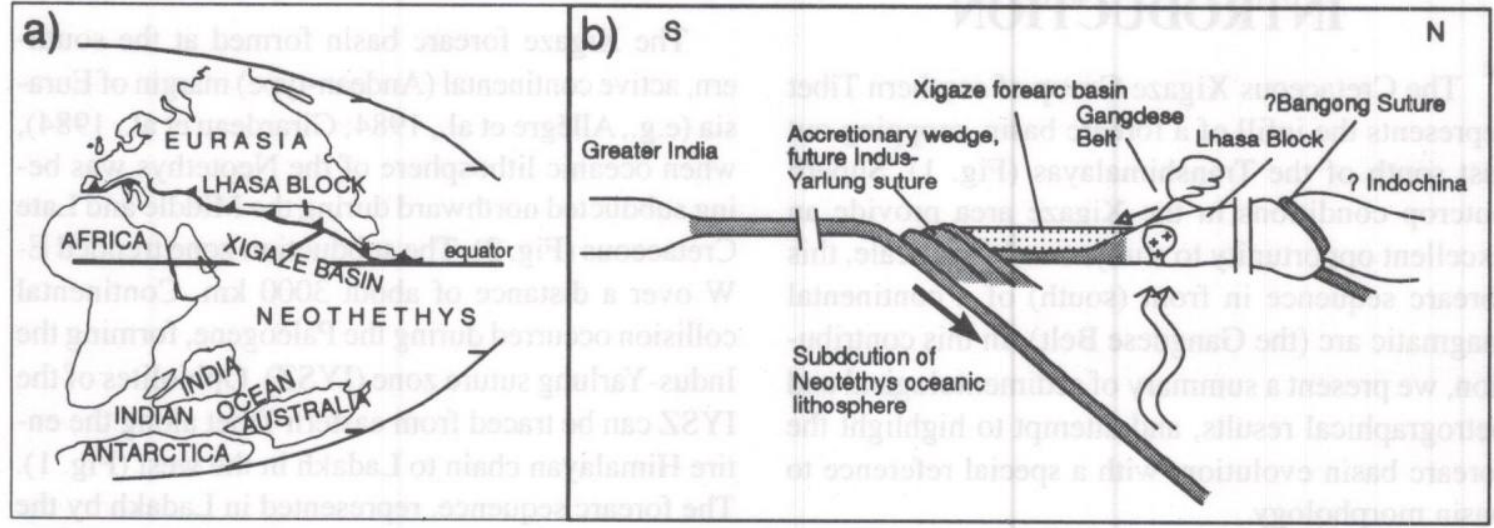

Fig. 2 a: Reconstruction of continents and oceans for the Neotethys realm for Middle Cretaceous time (simplified after Sengör et al., 1988). b: Schematic plate tectonic profile showing the Middle to Late Cretaceous constellation during Neotethys subduction, magmatism on the Lhasa Block and sedimentation into the Xigaze forearc basin. 
The petrography and geochemistry of the deposits is dealt with by Dürr (1993, submitted).

\section{GEOLOGIC SETTING}

To the north of the Xigaze Group, the magmatic arc rocks of the Gangdese Belt form the northernmost unit of the Himalayas, the Transhimalayas. Further north, the Tibetan Plateau is formed by the Lhasa and Qantang blocks, which are separated by the Bangong Nujiang suture zone of Middle Jurassic (Xu et al., 1985; Searle et al., 1987) to Early Cretaceous age (Allégre et al., 1984). To the south of the Xigaze Group, ophiolites of the IYSZ are present, as well as a Triassic-Liassic flysch unit representing slope deposits of the northern Indian passive margin. To the south of this unit, the Tethys Himalayas comprise Paleozoic to Early Tertiary sediments deposited on the northern, passive continental margin of Greater India.

The studied region extends about $80 \mathrm{~km}$ to the west and $40 \mathrm{~km}$ to the east of the city of Xigaze (Fig. 3). Further east, no forearc deposits are known, and ophiolites are absent east of Lhasa. Aside from representing remnants of the Neotethys oceanic crust, the ophiolites in the region of our study are interpreted as locus of major right-lateral strike-slip faulting accommodating extrusion of the Indochina Block during the Indo-Asia collision (Peltzer and Tapponnier, 1988), and as locus of the Gangdese Thrust (Yin et al., 1994).

To the north, the Xigaze Group in the studied region neighbours different units along strike (Fig. 3 ), always with tectonic contacts. Most frequently, the Xigaze Group is bordered by the Eocene to Oligocene Qiuwu Formation (e.g., Wu et al., 1977), a series of cyclic, fluvial silt- and sandstones and conglomerates which rests unconformbly on batholiths of the Gangdese Belt (e.g, Einsele et al., 1994). The Qiuwu Fm may represent a final phase of sedimentation into the Xigaze forearc basin (Einsele et al., 1994). In other places the Xigaze Group is in contact with shallow water carbonate to marl (cf. Fig. 3), representing shelf deposits and including rudist patch reefs. The carbonates cropping out today are of Aptian/Albian (Cherchi and Schroeder, 1980; Bassoullet et al., 1984) to at least Upper Albian age (Wiedmann and Dürr, in press). A resedimented Turrilites in a carbonate pebble from a Xigaze Group conglomerate (Wiedmann and Durr, in press) indicates, however, that carbonate production on the shelf continued to at least the Cenomanian, concurrently with sedimentation into the forearc ba$\sin$. The geological position of the carbonates and their age suggest that they were deposited on a shelf forming the northern rim of the forearc basin. This is corroborated by volcaniclastic intercalations in these limestones, indicating a spatially intermediate position between the forearc basin deposits and their volcanic source. We do not include the shelf deposits into the Xigaze Group, as has been done previously (e.g., Bassoullet et al., 1984; Girardeau et al., 1984), because these sediments are better correlatable in terms of facies and fossil content with carbonate intercalations in the Middle Cretaceous Takena Series of the Lhasa Block (e.g., Leeder et al., 1988).

In the west, the Xigaze Group is in contact with batholiths of the Gangdese Belt (Fig. 3). Magmatic arc rocks can be traced along essentially the entire chain of the Himalayas (Fig. 1). Diorites and granodiorites of the Gangdese Belt gave radiometric ages of between $94 \mathrm{Ma}$ and $41 \mathrm{Ma}$ (Maluski et al., 1982; Schärer et al., 1984). Coulon et al. (1986) report two volcanic phases of 60-50 Ma and 15-10 $\mathrm{Ma}$, respectively. The volcaniclastic character of the Xigaze Group shows that volcanic activity in the magmatic arc was well in progress by Middle Cretaceous times. However, Cretaceous volcanics have been completely removed by erosion.

Recently, a major southward thrust in the eastern Transhimalayas has been proposed (Yin et al., 1994). These authors assume that this Gangdese Thrust was responsible for the discontinuous occurrence of the Xigaze Group along strike. To the east of the area investigated here, the Gangdese Thrust is supposed to be located at the southern termination of the Gangdese Belt, which accordingly is overthrust onto the Xigaze Group, thus burying it. In the Xigaze area, Yin et al. (1994) locate the Gangdese Thrust south of the Xigaze Group, which is therefore not buried 


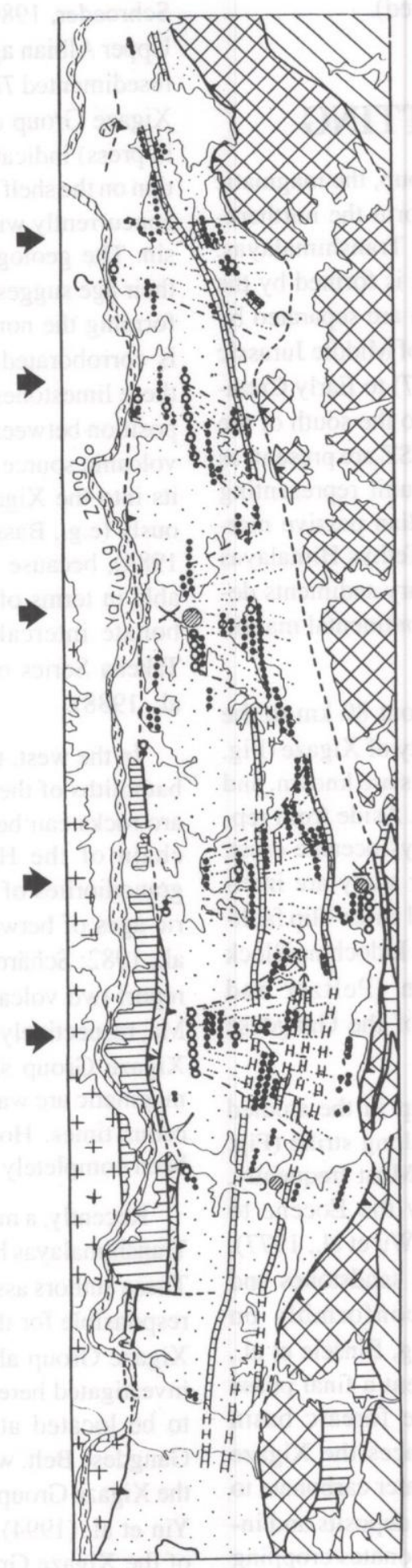

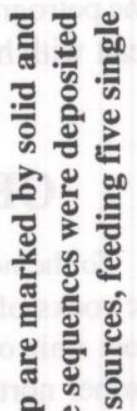

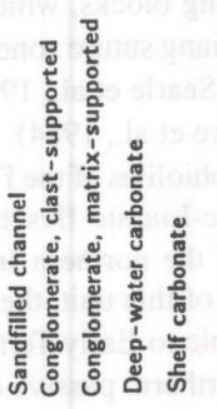

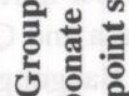
올 를 政 果 政 ํํㄹ. 홍

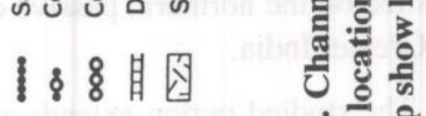
담

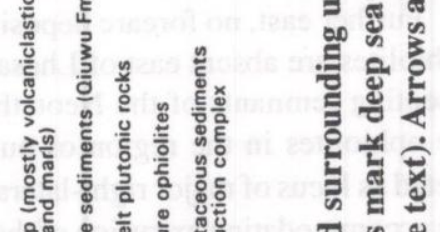

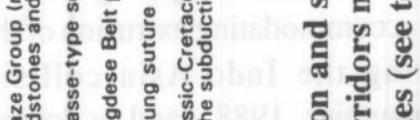

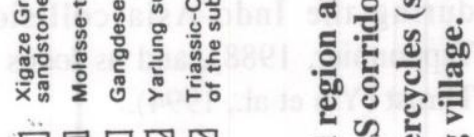

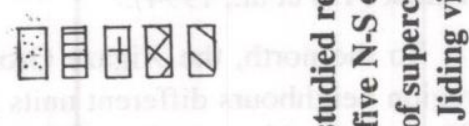

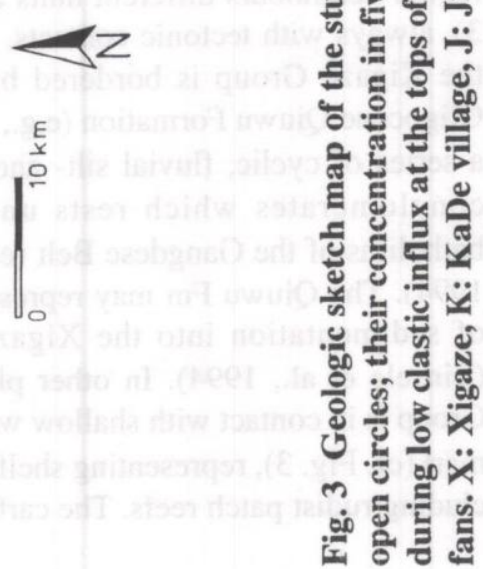


beneath the Gangdese Belt. However, primary pinching out of oceanic crust, which floored the Xigaze basin, could have caused the eastern basin termination, and is held responsible for the discontinuity of forearc deposits along the Himalayan chain to the west (Einsele et al., 1994).

\section{XIGAZE GROUP DEEP SEA CLASTIC FANS}

The Xigaze Group in the studied region consists of an about $7 \mathrm{~km}$ thick sequence of sediments; predominantly shale, silt- and sandstone, as well as minor conglomerates and hemipelagic marls (Fig. 4). We subdivide the Xigaze Group into four formations, based on a supercyclicity of the sequence described below. The four formations are the Jiangquinzhe, Tashilunpo, KaDe, and Jiding formations (Fig. 4).

The original thickness of the Xigaze Group was probably in the order of $12 \mathrm{~km}$ (Dürr, 1993), of which the upper part has been removed, probably by erosion. The present tectonic structure in the study area is that of a large synclinorium with its axis trending E-W (Shakleton, 1981; Burg \& Chen, 1984; Ratschbacher et al., 1992). The southern limb of the structure is largely absent for tectonic reasons (cf. Fig. 3). Due to this structure, Xigaze Group sediments generally young southward, i.e. the stratigraphically lowest rocks crop out in the north. Based on strain analyses and restored sections, Ratschbacher et al. (1992) estimated a minimum basin paleowidth of 66 $\mathrm{km}$.

In the investigated area, five single fans were lined up in an E-W direction and appear to have been regionally stable. The single fans were spaced between ca. 10 and $20 \mathrm{~km}$ apart and overlapped laterally in their lower fan regions. The stability of fan locations is interpreted to result from stable sediment point sources in the hinterland, constantly supplying sediment to the single fans (Einsele et al., 1994). Most probably, these point sources were small to mediumsized rivers. Fan locations were determined by the regional distribution of channel fills, displaying five channel-rich corridors which widen southward (Fig. 3). However, the stratigraphically lowest Jiangqinzhe
Fm does not show this concentration of channel fills (cf. Fig. 3). This indicates that the single fans, and accordingly the sediment point sources, were not established until sedimentation into the forearc basin was well in progress. Paleocurrent directions in the sediments are generally to the south in channel fills, and show directions from east over south to west in interchannel deposits.

In terms of facies associations typical of deep sea clastic fans (e.g., Nelson and Nilsen, 1984; Mutti and Normark, 1987; Shanmugam and Moiola, 1988), the distality of the depositional environment of the Xigaze Group increases southward, in agreement with southward paleoflow and fan widening. Thus, channel-fill/overbank/interchannel facies associations for the upper and mid fan occur in the north (with and without large feeder channels, respectively), comprising the Jiangqinzhe and Tashilunpo formations, and pass southward into sand sheet/lobe deposits of the lower fan (KaDe Fm), and finally into shaly deposits with distal turbidites of the basin plain realm (Jiding Fm). It is important to note that the formations were not defined as sequences characterising the fan regions, but that the identity of supercycles and deposits of single fan regions is coincidental.

Biostratigraphic control in the Xigaze Group is extremely poor due to a very low grade metamorphic overprint (see below) and the predominant flysch-like rock facies, resulting in an extremely poor preservation of microfossils and a rarity of macrofossils, respectively. Volcaniclastic sedimentation probably started at the Aptian/Albian boundary, indicated by an Upper Albian ammonite Mortoniceras from a stratigraphically intermediate position, as well as by volcaniclastic intercalations in Aptian/Albian shelf carbonates. A resedimented Middle Cenomanian ammonite Turrilites shows that the preserved sediment pile includes deposits at least that young. According to Herm et al. (1983), deep water sedimentation continued to at least the Late Turonian.

The Tashilunpo, KaDe and Jiding formations each represent one of three fining upward supercycles. Huge conglomerate-filled channels with 


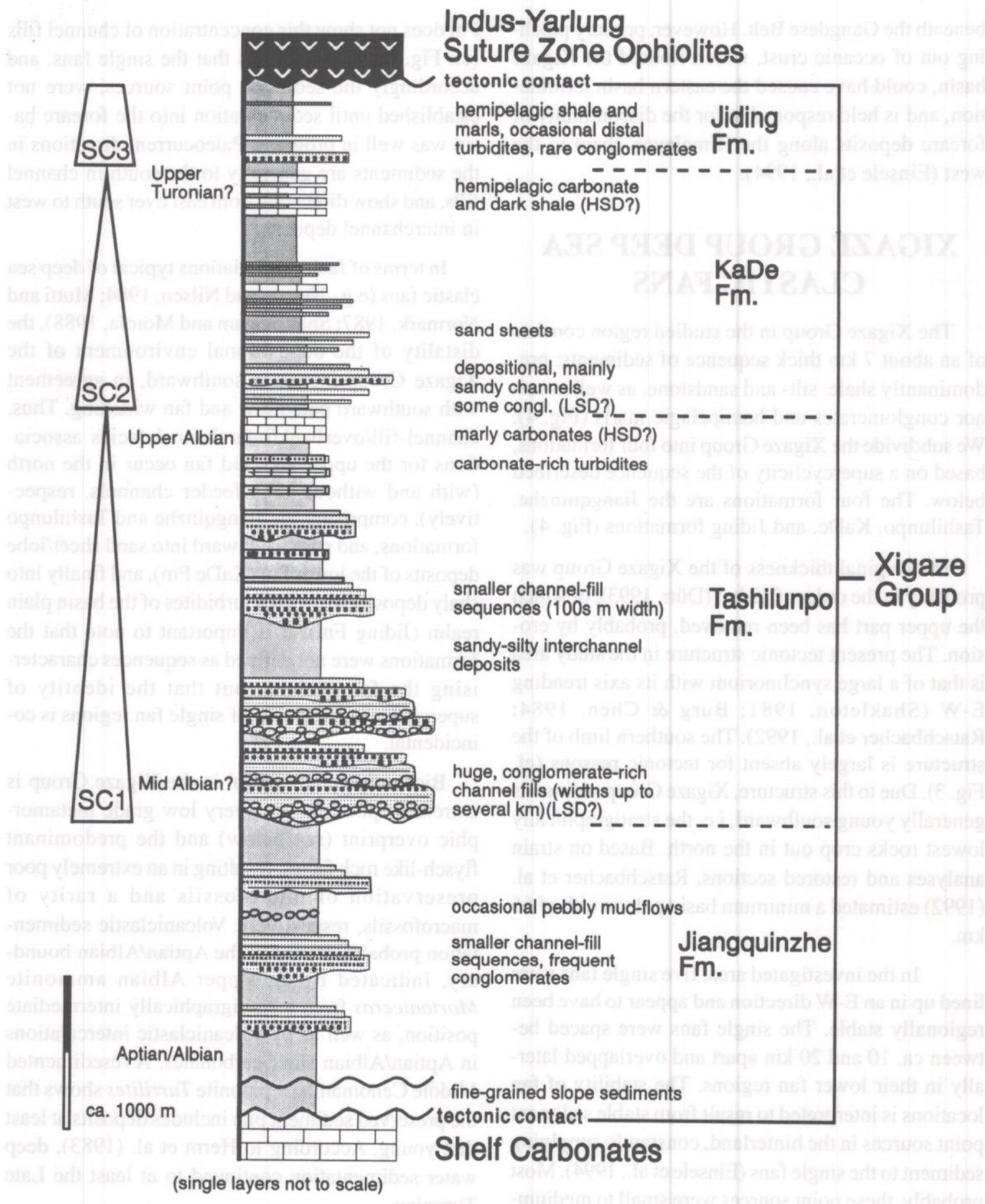

Fig. 4 Simplified, idealized columnar section of the Xigaze Group. SC1-3, fining-upward supercycles; LSD?, HSD?, possible sea level lowstand and highstand deposits, respectively. The darkness of shading indicates shale-richness. For datings, see text. At bottom of section, tectonic contact exists also to Gangdese Belt plutons and to Early Tertiary Qiuwu Formation sedimentites. 
Xigaze Forearc Basin

widths of up to several kilometers mark high influx at the supercycle bases (cf. photo in Fig. 8), whereas channel sizes, and sediment influx, strongly decrease toward the tops. During periods of high influx, the fans had their largest extension; with low influx, they were much smaller and wide parts of the forearc basin were dominated by marly, hemipelagic sedimentation marking supercycle tops. The Jiangqinzhe Formation comprises pre-supercycle deposits; interchannel sand- to siltstone as well as smaller, mainly sandy channel fills, with no superior thinning or thickening upward tendency. The large channel fill in the city of Xigaze and equivalent channel fills along E-W strike (Fig. 3) mark the base of the first supercycle, and the base of the Tashilunpo Fm. Sediment influx was controlled either by eustatic sea level fluctuations, by step-like tectonic uplift in the hinterland, or by both processes. Arguments in favour of sea level changes are given by the sediment composition (see below), and by the fact that the Middle to Late Cretaceous probably was a time of high-amplitude third order eustatic fluctuations (see Haq et al., 1987). Tectonic versus eustatic control on sediment influx of the Xigaze Group is discussed in detail by Dürr (submitted).

\section{SEDIMENTARY COMPOSITION}

The silicilastic deposits of the Xigaze Group are generally made up of volcaniclastic components shed from the Gangdese Belt. Intercalated bentonites and tuffaceous deposits indicate that the Gangdese Belt was active concurrently to sedimentation into the Xigaze basin. By far the largest part of material in the Xigaze Group is of andesitic composition, shown by the petrography as well as chemistry of volcanic pebbles and sandstones (Durr, 1993, submitted). There are, however, significant variations in the sediment compositions in space and time.

Second to andesite pebbles, carbonates are most abundant in conglomerates in the eastern section of the study area (Fig. 5). In the west, only small amounts of carbonate pebbles are present in older conglomerates, but absent in younger ones. Shown by their facies and fossil content, these carbonates are erosive products of the shelf bordering the Xigaze Basin to the north which was exhumed due to arc uplift. Andesite and carbonate both feature large pebble sizes of up to one meter in diameter, suggesting

$\mathbf{N}$

\section{LIMESTONES}

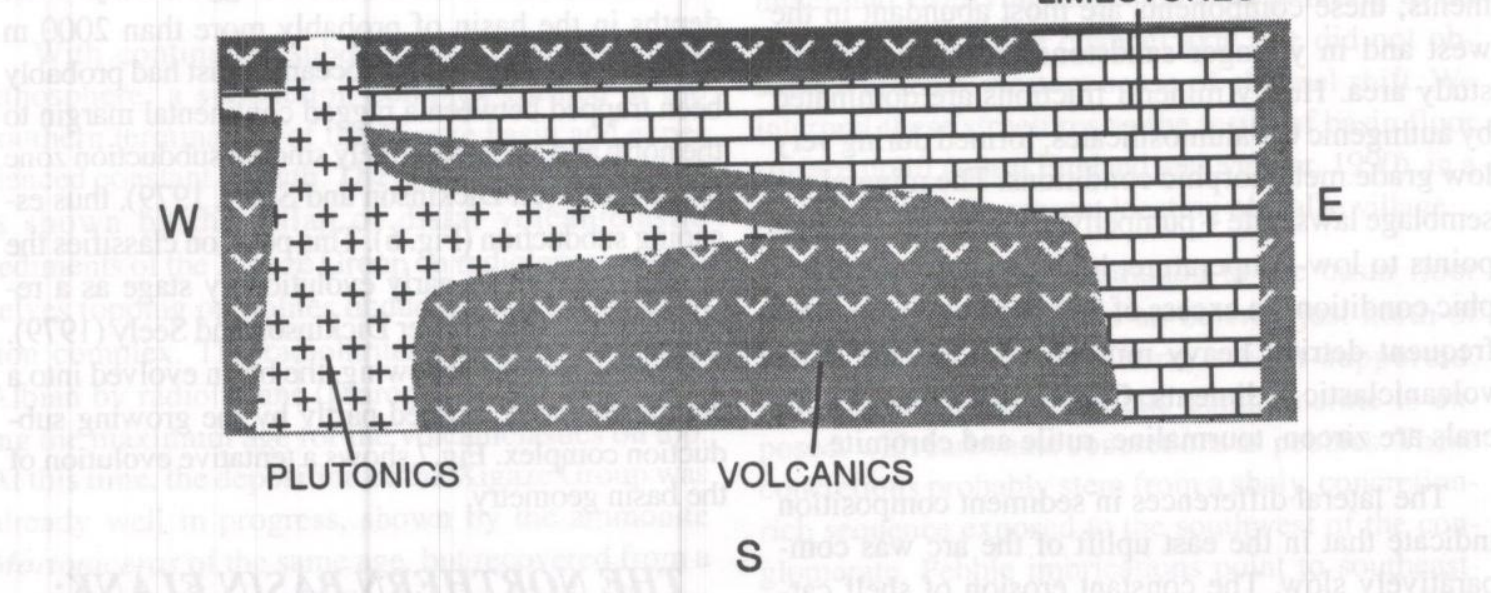

Fig. 5 Regional trends in the composition of conglomerates of the Xigaze Group, dominated by andesite. Note eastward increasing porportions of reworked shelf carbonates, whereas plutonic components are abundant in western regions. For further explanations, see text. 


\section{S. B. Durr et al.}

that the sources of both lithologies were very near to the basin, and therefore in essentially the same area.

Tonalitic pebbles appear at the expense of carbonate pebbles in the western study area, with increasing amounts towards younger deposits. Despite the calcalkaline composition of the plutonic rock, zircon typologies suggest a collision-related genesis of the tonalite, and are therefore against a genetic relationship of the tonalite to the andesites. Sedimentary pebbles, chert, sand-, silt-, and mudstone, are present in minor amounts in all conglomerates and, at least partly, represent basinal intraclasts. The variety of extrabasinal lithologies present as pebbles is thought to reflect those lithologies that were eroding on the southern Lhasa Block, i.e. in the arc area, because the pebble lithologies present are unstable during prolonged transport distances. Regardless of lithology, pebbles are generally sub- to well-rounded, suggesting fluvial transport prior to deposition in the Xigaze basin.

Major sandstone components are volcanic lithic fragments, identical in texture and mineralogy to the andesite pebbles, and plagioclase. Quartz may reach $50 \mathrm{vol} . \%$ in some samples. Clastic carbonate, detrital mica and metamorphic lithic grains are minor constituents. Conglomerate compositional trends are mirrored by the sandstones: those from the east largely lack quartz, mica, and metamorphic fragments; these components are most abundant in the west and in younger sandstones from the central study area. Heavy mineral fractions are dominated by authigenic $\mathrm{Ca}$-alumosilicates, formed during very low grade metamorphic conditions. The mineral assemblage lawsonite + pumpellyite + chlorite + titanite points to low-temperature, high pressure metamorphic conditions in excess of $3 \mathrm{~kb}$. Apatite is the most frequent detrital heavy mineral, as expected from volcaniclastic sediments. Other detrital heavy minerals are zircon, tourmaline, rutile and chromite.

The lateral differences in sediment composition indicate that in the east uplift of the arc was comparatively slow. The constant erosion of shelf carbonates points to a low rate of exhumation of the arc. In the west, exhumation was slightly stronger, resulting in removal of the carbonates and enabling the erosional level to affect deeper, plutonic rock.
This, at least partially, accounts for higher quartz contents in the sandstones. Elsewhere (Dürr, submitted) it is argued that a smaller part of the sediment derived from a distant exhuming orogen where ophiolitic and metamorphic lithologies were eroding. This source delivered chromite as well as the metamorphic components rutile, mica and metamorphic lithic fragments, respectively, to the Xigaze Group.

The homogenous sediment composition throughout time in the eastern section of the study area supplies an important argument against a tectonic control on sediment influx. Tectonic pulses, causing arc dissection, should accordingly generate changes in sediment composition towards higher quartz and feldspar contents, reflecting lithologies from deeper crustal levels. No compositional trends in time are present in the eastern section, but supercycles are well developed along the entire length of the study area.

\section{BASIN EVOLUTION AND MORPHOLOGY}

The forearc basin was most probably floored by oceanic crust; this was a prerequisite for sufficient space to accomodate a several $\mathrm{km}$ thick sediment sequence in a rather short time (e.g., Einsele, 1992). Additonally, an oceanic floor is suggested by water depths in the basin of probably more than $2000 \mathrm{~m}$ (Einsele et al., 1994). The oceanic crust had probably been trapped between a ragged continental margin to the north and a comparatively smooth subduction zone to the south (cf. Dickinson and Seely, 1979), thus escaping subduction (Fig. 6). This position classifies the Xigaze basin in its early evolutionary stage as a residual forearc basin after Dickinson and Seely (1979). As is shown in the following, the basin evolved into a composite basin, floored partly by the growing subduction complex. Fig.7 shows a tentative evolution of the basin geometry.

\section{THE NORTHERN BASIN FLANK: THE THICKENING MAGMATIC ARC}

As is argued above, thickening of the Gangdese Belt was low when the preserved sediments of the 


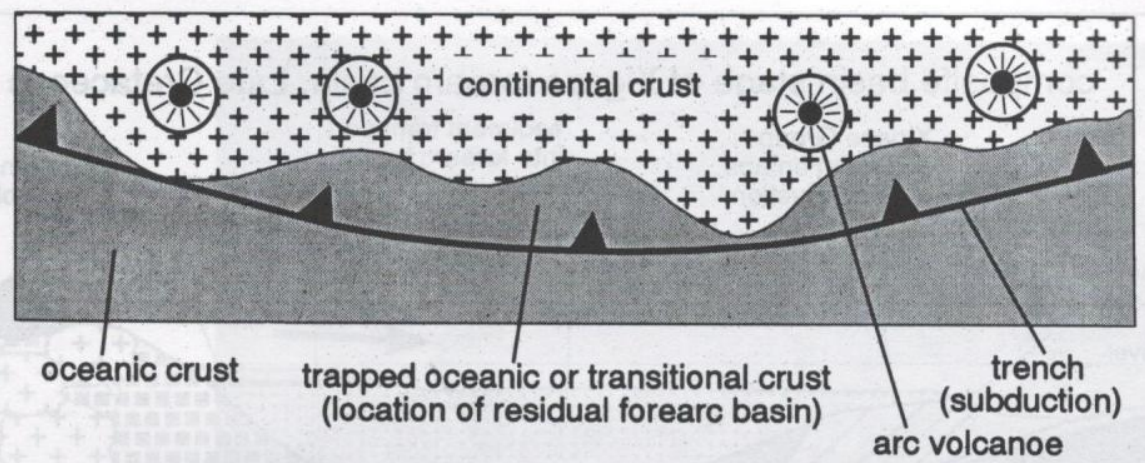

Fig. 6 Plan view of a theoretical continental margin arc-trench system. The subduction zone is smoothly arcuate, whereas the continental margin is ragged. A residual forearc basin forms where oceanic and/ or transitional crust is trapped between protrusions of the continent.

Xigaze Group was deposited. Pluton emplacement, as a major process of arc crustal thickening, was in progress by Cenomanian time, shown by U-Pb systematics from zircons which deliver concordant ages of up to $94 \mathrm{Ma}$ for Gangdese Belt diorites about 70 km ENE of Xigaze (Schärer et al., 1984). Uplift accelerated in the Late Cretaceous, because until the Eocene the arc experienced several km of exhumation, which is shown by the onlap of molasse-type sediments of the Qiuwu Formation of this age onto Gangdese Belt plutons (Einsele et al., 1994).

\section{SOUTHERN BASIN FLANK: THE GROWING SUBDUCTION COMPLEX}

With continuous subduction of the Neotethys lithosphere, a subduction complex formed at the southern termination of the Xigaze basin and experienced constant growth. The growth of the complex is shown by the onlap of distal volcaniclastic sediments of the Xigaze Group on radiolarites, themselves topping ophiolites obducted into the subduction complex. The radiolarites are dated as Upper Albian by radiolarians (Marcoux et al., 1982), giving the maximum age for the volcaniclastics on top. At this time, the deposition of the Xigaze Group was already well in progress, shown by the ammonite Mortoniceras of the same age, but recovered from a stratigraphically intermediate position in the Xigaze Group (Fig. 4). However, growth of the subduction complex was not strong enough to generate a morphological ridge at the southern forearc termination (Fig. 7), at least not for the time span recorded by the preserved sediments. Such a ridge would have been oriented approximately parallel to the subduction zone (east-west), and would have caused a deflection of current directions parallel to the basinaxis (east-west). Xigaze Group paleoflows in channels do not show a deflection from their generally southward direction, suggesting that the growth of the sedimentary wedge of the Xigaze Group kept pace with subduction complex upbuilt.

Indirect evidence for subduction complex growth is supplied by the geometry of some channel fills. In the south, a number of these display lateral accretion of their sediments (Fig. 8). The laterally accreted strata always dip to the east at a steeper angle than under-and overlying deposits, thus pointing to an eastward shift of the channel axis. We did not observe a reverse, western sense of channel shift. We interpret these structures as the result of basin floor surface uplift (sensu England and Molnar, 1990), in a region west of the present location of $\mathrm{KaDe}$ village.

Synsedimentary exhumation of the basin floor to the west is recorded in an outcrop just north of KaDe village (Fig.9). There, a clast-supported, intraformational monomictic conglomerate is exposed, with carbonate concretions as pebbles. These concretions probably stem from a shaly, concretionrich sequence exposed to the southwest of the conglomerate. Pebble imbrications point to southeastward paleoflow, suggesting that the source rock experienced exhumation in a region to the west.

These observations are taken as evidence for synsedimentary tectonic movements with a vertical 


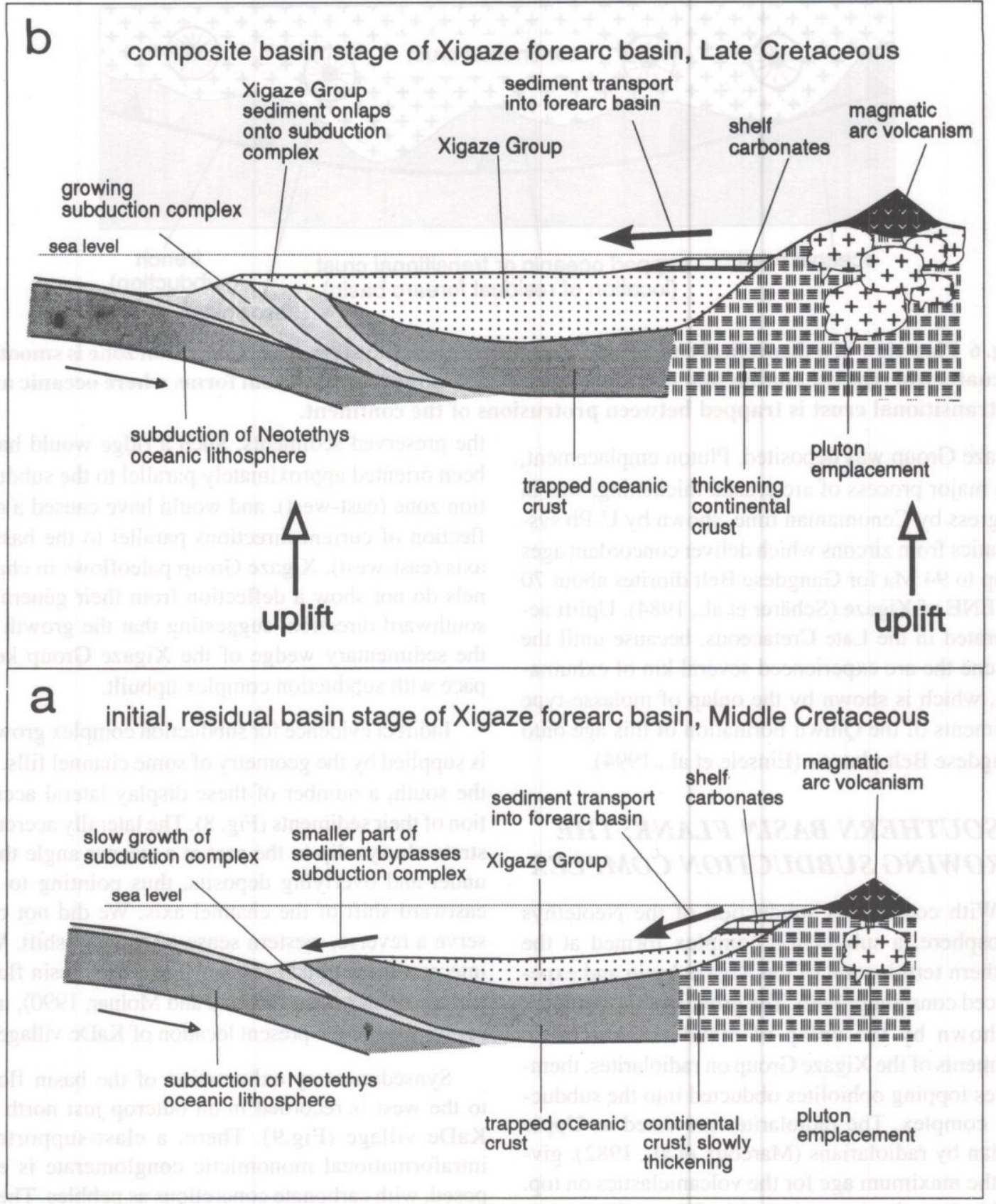

Fig. 7 a: Profile showing Xigaze forearc basin morphology during the initial, residual basin stage. The basin is relatively deep and narrow; neither the continental arc nor the subduction complex are yet uplifted significantly. b: Theoretical composite basin stage. The basin has shallowed and widened; the crust beneath the arc has thickened and the subduction complex has grown upwards and outwards. Note that this is a tentative reconstruction; it may be possible that Xigaze basin shallowing by growth of both basin flanks was preempted by continental collision, terminating the basin history. 

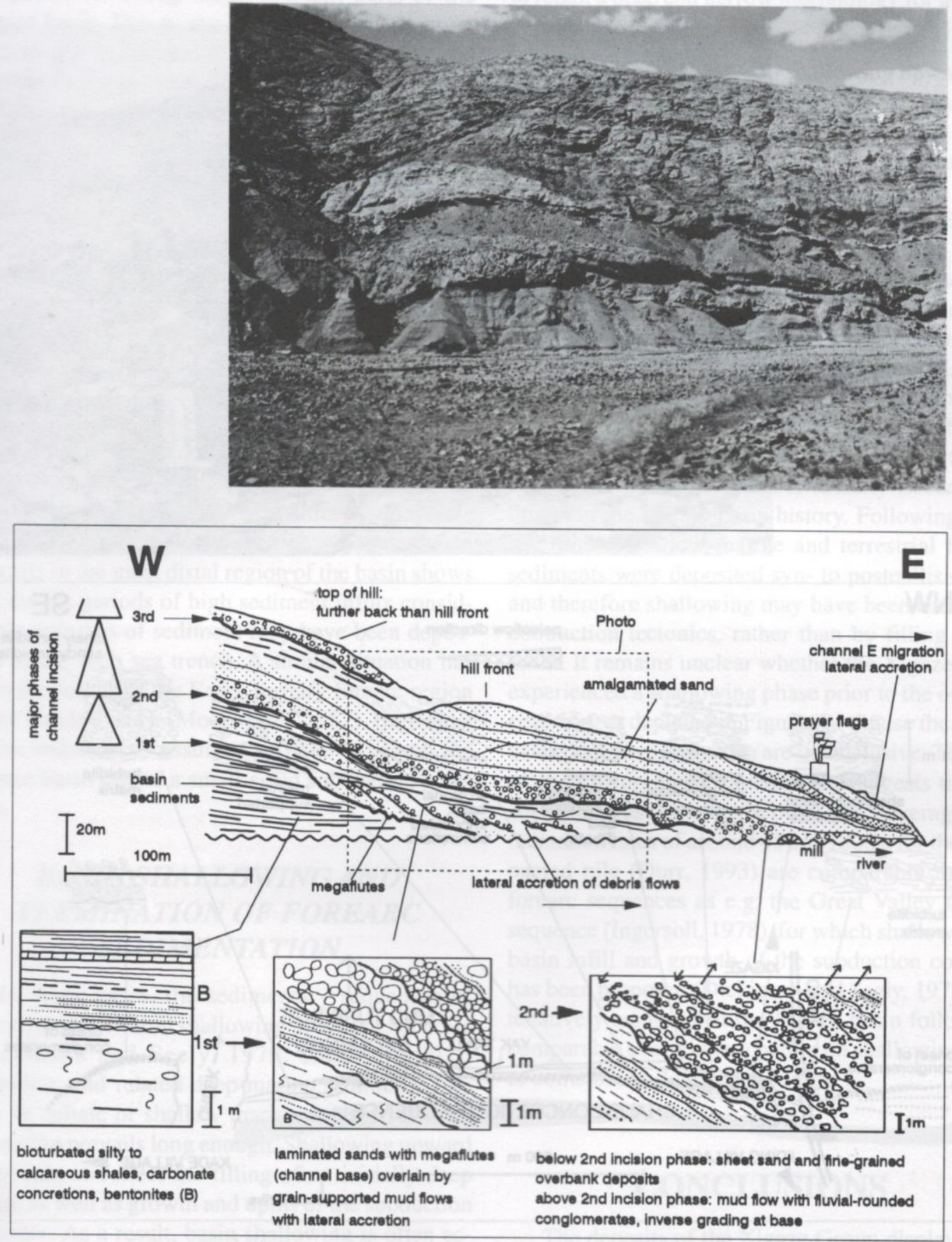

Fig. 8 Detail of large channel fill near the village KaDe. Section in photo at top is indicated by hatched rectangle. The deposits show three major phases of channel incision. Debrites deposited during the first incision phase and coarse sands of the second phase show lateral accretion, indicating E-ward migration of the channel axis. 


\section{S. B. Durr et al.}
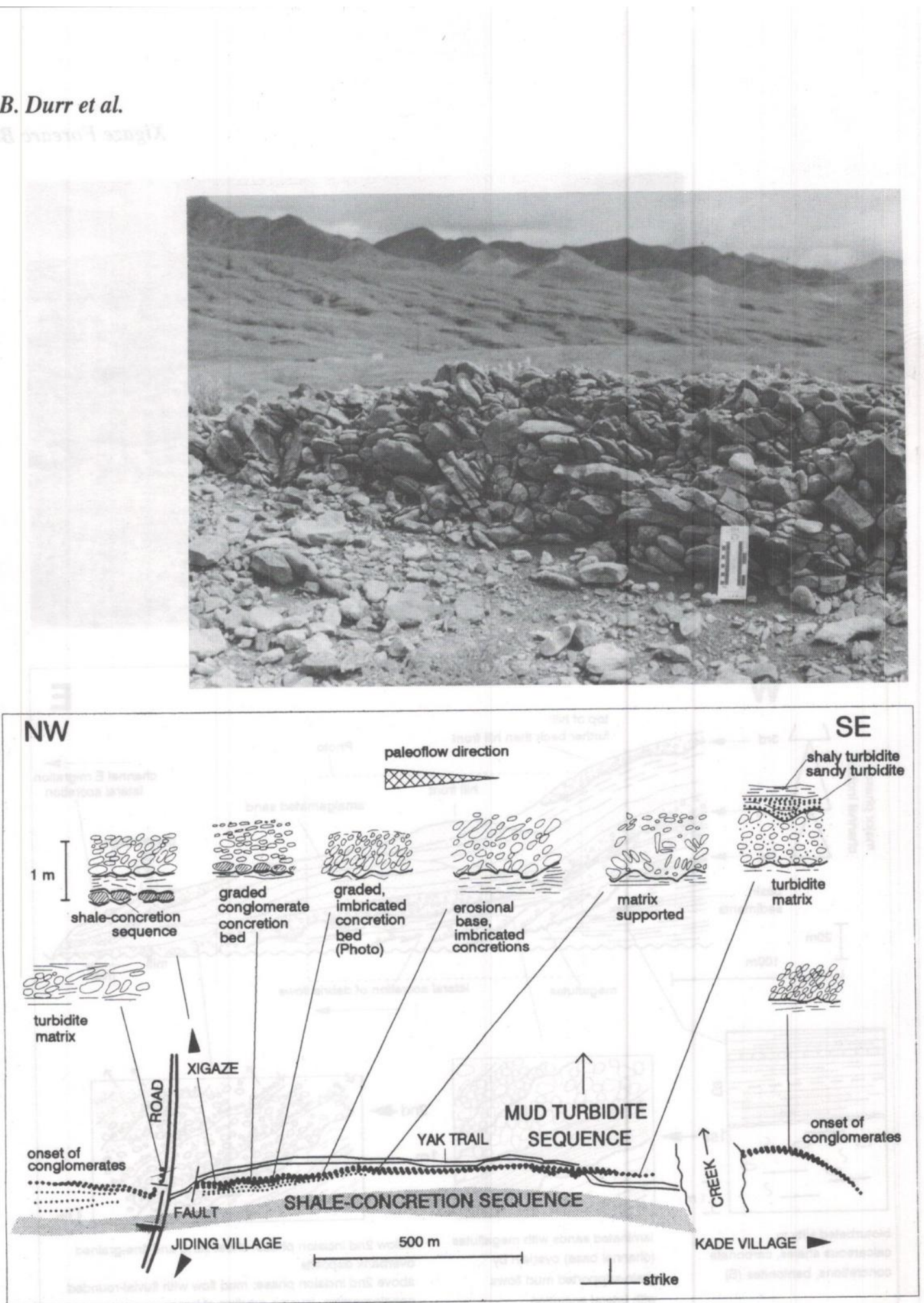

Fig. 9 Sketch map (plan view) of an imbricated carbonate concretion conglomerate, $1 \mathrm{~km} \mathrm{~N}$ of KaDe. Paleoflow was from the NW and pebbles were probably derived from a shale-concretion sequence stratigraphically below. The strike is NW-SE, and not E-W as generally in the study area, due to complicated folding in this region. The photo at top shows the center detail sketch. 
Xigaze Forearc Basin

component affecting distal, western parts of the Xigaze basin. Due to the lack of equivalent structures in more proximal sediments in the north, we propose that tectonism was caused by subduction complex growth, resulting in uplift of the southern basin flank.

The inference that the subduction complex did not serve as an outer basin dam indicates that part of the sediment delivered into the basin was able to bypass the subduction complex to be deposited in the subduction trench. This is further corroborated by voluminous channel fill deposits found in the most distal exposed section of the Xigaze Group, near the village $\mathrm{KaDe}$ (cf. Fig. 3). This channel fill is incised into marly basin plain deposits and consists of thick conglomerate and sandstone packages (Fig. 8). It formed when sediment influx rapidly increased, marking the base of the second sediment supercycle (cf. Fig. 4). The presence of even very coarse-grained deposits in the most distal region of the basin shows that during periods of high sediment influx considerable volumes of sediment may have been deposited in the deep sea trench. A similar situation has been proposed for the Early Tertiary forearc region of the Sunda Trench (Moore et al., 1982). Here most of the sediment is assumed to have bypassed the forearc basin due to a small-sized subduction complex.

\section{BASIN SHALLOWING AND TERMINATION OF FOREARC SEDIMENTATION}

In many cases, the sedimentary sequences of forearc basins exhibit shallowing upward tendencies (Dickinson and Seely, 1979; Einsele, 1992). Turbiditic and related deep-marine sediments give way to deltaic or shallow marine deposits, if sedimentation prevails long enough. Shallowing upward is thought to reflect the filling of an initially deep basin, as well as growth and uplift of the subduction complex. As a result, basin shallowing is often accompanied by basin widening, as sediment onlaps onto accreted material of the subduction complex (Fig. 7). With low sediment influx and slow growth of the subduction complex, a forearc basin will tend to retain a deep and narrow morphology for a longer period.

In the Xigaze Group, no shallowing upward tendencies in the deeper water deposits are visible in our study area. Shallow marine sediments of the forearc region are, however, exposed ca. $400 \mathrm{~km}$ west of Xigaze (Wan et al., 1982; Wan, 1987). These sediments yielded Paleocene to early Eocene foraminiferal and bivalve assemblages. The terrestrial Paleocene/Eocene Qiuwu sediments also indicate significant shallowing in the forearc region. New paleomagnetic (Klootwijk et al., 1991; Patzelt et al., 1994) and paleontological results (Jaeger et al,, 1989) suggest that the onset of continental collision may have been as early as the Cretaceous/Tertiary boundary, with complete closure for the eastern part of the Neotethys in the Late Paleocene/Early Eocene, terminating the forearc basin history. Following these results, the shallow marine and terrestrial forearc sediments were deposited syn- to postcollisionally, and therefore shallowing may have been caused by contraction tectonics, rather than by filling of the basin. It remains unclear whether the Xigaze Basin experienced a shallowing phase prior to the onset of collision, as depicted in Figure 7, because the observations and available data are inconclusive. The lack of shallowing-upward tendencies suggests that basin filling was slow. On the other hand, average sedimentation rates of around $45 \mathrm{~cm} / 1000$ a for the compacted pile (Durr, 1993) are comparable to other forearc sequences as e.g. the Great Valley forearc sequence (Ingersoll, 1978), for which shallowing by basin infill and growth of the subduction complex has been proposed (Dickinson and Seely, 1979). We tenatively assume that the Xigaze basin followed a comparable evolutionary path with shallowing prior to collision, as depicted in Figure 7.

\section{CONCLUSIONS}

The deposits of the Xigaze Group display complex sedimentary and provenance patterns, resulting from the interactions of processes most of which, but not all, are related to Neotethys subduction under Eurasia. 


\section{S. B. Durr et al.}

The largest part of the sediment was derived from the basin-near, active Gangdese Belt, including an adjacent carbonate shelf. Magmatic arc activity was responsible for a constant supply of detritus. Uplift and dissection following arc crustal thickening was yet of a small magnitude. The beginning of arc dissection is recorded by a change in sediment composition in the western part of the study area, where tonalitic detritus appeared at the expense of shelf carbonate. Eustacy as external factor appears to have modified the amount of sediment influx into the ba$\sin$. As a result, three fining-upward supercyles formed. The first drastic increase in influx at the base of the first supercycle additionally established five regionally stable sediment point sources (probably the mouths of smaller rivers), which were responsible for the location of five deep sea clastic fans in the Xigaze Basin. These fans were the major loci of sediment deposition.

The basin morphology and evolution was controlled by subduction-related processes. The southern basin flank was formed by the slowly growing subduction complex, the northern flank by the thickening Gangdese Belt. Synsedimentary tectonic movements in the basin may have been caused by subduction complex growth, but substantial thickening and uplift of the Gangdese Belt did not occur until the Late Cretaceous. However, no sedimentary record of this time is preserved in the Xigaze Group.

The marine phase of the forearc basin was terminated by the Early Tertiary. It is unclear whether shallowing was related to a sediment supply exceeding the accommodation space, or to first contractional tectonics following the onset of continental collision of Greater India with Eurasia. Based on comparisons with the evolution of other forearc basins, we prefer the first solution.

\section{ACKNOWLEDGEMENTS}

Many discussions with W. Frisch, L. Ratschbacher, and numerous colleagues from the Tübingen institutes greatly improved this study. Field work in Tibet was organised by the Chengdu Institute of Geology and Mineral Resources, China. In particular, Huang Yiyas organisatory skills and field assistance were invaluable. Financial support of this work was granted by the German Research Foundation and by the Ministry of Geology and Mineral Resources of the P.R. China. A review by Gerhard Fuchs is greatly acknowledged.

\section{REFERENCES}

Allègre, C.J., Courtillot, V. and 33 others, 1984, Structure and evolution of the Himalaya-Tibet orogenic belt. Nature, v. 307 , pp. 17-22.

Bassoullet, J.P., Colchen, M., Mascle, G., and Wang Naiwen, 1984, Les ensembles sédimentaires de la zone du Tsangpo (Lhazê, Lhasa, Linzhu). In Mercier, J.L., and Li Guancen, eds., Mission Franco-Chinoise au Tibet 1980. Comptes Rendues de l'Academie de Sciences, pp.133-153.

Burg, J.P. and Chen, G.M., 1984, Tectonics and structural zonation of southern Tibet. Nature, v. 311, pp. 219-223.

Cherchi, A. and Schroeder, R. 1980, Parorbitolinoides hedini $n$. gen. n. sp., grand Formainifère du Crétacé inférieur du Tibet méridional. Comptes Rendues de l'Academie des Sciences, v. D 291, pp. 385-388.

Coulon, C., Maluski, H., Bollinger, C., and Wang, S., 1986, Mesozoic and Cenozoic rocks from central and southern Tibet: ${ }^{39} \mathrm{Ar}-{ }^{40} \mathrm{Ar}$ dating, petrologic characteristics and geodynamic significance. Earth and Planetary Science Letters, v. 79 , pp. 281-302.

Dickinson, W.R., and Seely, D.R., 1979, Structure and stratigraphy of forearc regions. American Association Petroleum Geologists Bulletin, v. 63, pp. 2-31.

Dürr, S.B., 1993, The mid to early late Cretaceous Xigaze forearc basin (south Tibet): sedimentary evolution and provenance of sediments. Tübinger Geowissenschaftliche Arbeiten, A, $15,119 \mathrm{p}$.

Dürr, S.B., Provenance of Xigaze forearc clastics (Cretaceous): Tibetan magmatic arc infancy. Submitted to Geological Society of America Bulletin.

Dürr, S.B., and Ricken, W., Unique deep-sea fan associations in Tibet: the Cretaceous Xigaze Group. In preparation.

Einsele, G., 1992, Sedimentary Basins. Stuttgart (Springer), 628 p.

Einsele, G., Liu Baojun, Dürr, S., Frisch, W., Liu Guanghua, Luterbacher, H.P., Ratschbacher, L., Ricken, W., Wendt, J., Wetzel, A., Yu, G., and Zheng, H, 1994, The Xigaze forearc basin: evlution and facies architecture (Cretaceous, Tibet). Sedimentary Geology, v. 90, pp. 1-32.

England, P. and Molnar, P., 1990, Surface uplift, uplift of rocks, and exhumation of rocks. Geology, v. 18, pp. 1173-1177.

Gansser, A., 1991, Facts and theories on the Himalayas. Eclogae geologicae Helvetiae, v. 84, pp. 33-60.

Garzanti, E. and Van Haver, T., 1988, The Indus clastics: forearc basin sedimentation in the Ladakh Himalayas (India). Sedimentary Geology, v. 59, pp. 237-249.

Girardeau, J., Marcoux, J., and Yougong, Z., 1984: Lithologic 
and tectonic environment of the Xigaze ophiolite (Yarlung Zangbo suture zone, Southern China), and kinematics of its cmplacement. Eclogae geologicae Helvetiae, v. 77, pp. 153170.

Haq, B.U., Hardenpol, J., and Vail, P.R., 1987, Chronology of fluctuating sea levels since the Triassic. Science, v. 235, pp. 1156-1167.

Herm, D., Schröder, R., and Binggao, Z., 1983, Stratigraphic events during Cretaceous time in southern Xizang (Tibet). Terra Cognita, v. 3, p. 267.

Ingersoll, R.V., 1979, Evolution of the Late Cretaceous forearc basin, northern and central California. Geological Society of America Bulletin, v. 90, pp. 813-826.

Klootwijk, C., Gee, J.S., Peirce, J.W., and Smith, G.M., 1991, Constraints on the India-Asia convergence: paleomagnetic results from Ninetyeast Ridge. In: Weissel, J., Taylor, E., and Alt, J., eds., Proceedings ODP, Scientific Results, v. 121 , pp. 777-881.

Jaeger, J., et al., 1989, Paleontological view of the Deccan Traps, the Cretaceous/Tertiary boundary and the India/Asia collision. Geology, v. 17, pp. 316-319.

Leeder, M.R., Smith, A.B., and Jixiang, Y., 1988, Sedimentology, paleoecology and paleoenvironmental evolution of the 1985 Lhasa to Golmud geotraverse. In: Chengfa, Ch., Shakleton, R.M., Dewey, J.F., and Jixiang, Y., eds., The Geological evolution of Tibet. Philosophical Transactions of the Royal Society of London, v. A 327, pp. 107-143.

Liu Guanghua, 1992, Permian to Eocene sediments and Indian passive margin evolution in the Tibetan Himalayas. Tübinger Geowissenschaftliche Arbeiten, A, 13, 313p.

Liu Guanghua, and Einsele, G., 1994, Sedimentary history of the Tethyan basin in the Tibetan Himalayas. Geologische Rundschau, v. 83, pp. 32-61.

Maluski, H., Proust, F., and Xiao Xuchang, $1982,{ }^{39} \mathrm{Ar} /{ }^{40} \mathrm{Ar}$ dating of the trans-Himalayan calc-alkaline magmatism of southern Tibet. Nature, v. 298, pp. 152-154.

Marcoux, J., Girardeau, J., Fourcade, E., Bassoullet, J.P., Philip, J., Jaffrezo, M., Xuchang, X., and Chang Chengfa, 1987, Geology and biostratigraphy of the Jurassic and Lower Cretaceous series to the north of the Lhasa Block, (Tibet, China). Geodinamica Acta, v. 1, pp. 313-325.

Moore, G.F., Curray, J.R., and Emmel, F.J., 1982, Sedimentation in the Sunda Trench and forearc region. In: Legett, J.K., ed., Trench Forearc Geology: Sedimentation and Tectonics on Modern and Ancient Active Plate Margins. Geological Society Special Publications, v. 10, pp. 245-258.

Mutti, E. and Normark, W.R., 1987, Comparing examples of modern and ancient turbidite systems: Problems and concepts. In: Legett, J.K., and Zuffa, G.G., eds., Marine Clastic Sedimentology, Concepts and Case Studies, pp. 1-38. London (Graham \& Trotman).

Nelson, C.H. and Nilsen, T.H., 1984, Modern and Ancient DeepSea Fan Sedimentation. Lecture Notes on SEPM Short Course No. 14. Tulsa, Oklahoma (ed. SEPM), 404 p.

Patzelt, A., Li, H., and Appel, E., 1994, Paleomagnetic results from the Tethyan Himalaya of SW-Tibet: evidence for a former Greater India. Journal of Nepal Geological Society, v. 10, pp. 96-97 (Abstract 9th Himalaya-Karakorum-Tibet
Workshop, Kathmandu, Nepal, 1.-4.April 1994).

Peltzer, G., and Tapponier, P., 1988, Formation and evolution of strike-slip faults, rifts, and basins during the India-Asia collision: an experimental approach. Journal of Geopysical Research, v. 93 (B12), pp. 15082-15117.

Ratschbacher, L., Frisch, W., Chen, C. and Pan, G., 1992, Deformation and motion along the southern margin of the Lhasa Block (Tibet) prior to and during the Asia-India collision. Journal of Geodynamics, v. 14, pp. 1-31.

Ratschbacher, L., Frisch, W. and Chen, C., Kinematics of distributed deformation in S- and W-Tibet during and after the India-Asia collision. Journal of Geophysical Research, in press.

Schärer, U., Ronghua Xu, and Allégre, C.J., 1984, U-Pb Geochronology of Gangdese (Transhimalaya) plutonism in the Lhasa-Xigaze region, Tibet. Earth and Planetary Science Letters, v. 69 , pp. $311-320$.

Searle, M.P., Windley, B.F., Coward, M.P., Cooper, D.J.W., Rex, A.J., Tingdong, L., Xuchang, X., Jan, M.Q., Thakur, V.C. and Kumar, S., 1987, The closing of Tethys and the tectonics of the Himalaya. Geological Society of America Bulletin, v. 98 , pp. 678-701.

Sengör, A.M.C., Altiner, D., Cin, A., Ustaömer, T., and Hsü, K.J., 1988, Origin and assembly of the Tethyside orogenic collage at the expense of Gondwana Land. In: AudleyCharles, M.G, and Hallam, A., eds., Gondwana and Tethys. Geological Society of London Special Publication 37, pp. 119-181.

Shakleton, R.M.. 1981, Structure of Southern Tibet: report on a traverse from Lhasa to Khatmandu organised by Academia Sinica. Journal of Structural Geology, v. 5, pp. 413-428.

Shanmugam, G. \& Moiola, R.J., 1988, Submarine Fans: Characteristics, Models, Classification and Reservoir Potential. Earth Science Reviews, v. 24, pp. 383-428.

Wiedmann, J., and Durr, S.B., First ammonites from the Middle to Upper Cretaceous Xigaze Group, South Tibet, and their significance. Newsletters on Stratigraphy, in press.

Wan, X., 1987, Foraminifera biostratigraphy and paleogeography of the Tertiary in Tibet. Geoscience Journal of Beijing Graduate School, Wuhan College of Geology, v. 1, pp. 15-47.

Wan, Z., Li, G., Cao, Y., Gu, Q., Zhou, X., Zhang, S., Wu, Q. and Yuan, X., 1982, Tectonics of Yarlung-Zangbo suture zone, Xizang (Tibet) - Guide to geological excursion. Geological Society of Xizang, China, v. 4, pp. 1-49.

Wu, H.R., Wang, D.G. and Wang, L.C., 1977, The Cretaceous of Lhazé, Jiangze district, southern Xizang. Scienta geologica Sinica, v. 3, pp. 250-262.

Xu, R.-H., Schärer, U., and Allégre, C.J., 1985, Magmatism and metamorphism in the Lhasa Block (Tibet): a U-Pb geochronological study. Journal of Geology, v. 93, pp. 4157.

Yin, A., Harrison, T.M., Ryerson, F.J., Chen, W.J., Kidd, W.S.F., and Copeland, P., 1994, Tertiary structural evolution of the Gangdese thrust system, southeastern Tibet. Journal of Geophysical Research-Solid Earth, v.99, B9, pp. 18175-18201. 